\title{
Context of Sociocultural Knowledge in Discourse Construction
}

\author{
N. N. Boldyrev \\ G. R. Derzhavin: Honoured Scholar of Russian Federation, Doctor of Philology, Professor, vice-rector of research at Tambov State \\ University named after G.R. Derzhavin, President of Russian Cognitive Linguists Association \\ Email: boldyrev@tsu.tmb.ru
}

\author{
O. G. Dubrovskaya \\ Associate Professor of English Philology Department, PhD of Philology Sciences, Tyumen State University, Tyumen, Russia \\ Email: o_dubrovskaya@inbox.ru
}

Doi:10.5901/mjss.2015.v6n1s2p25

Abstract

The paper proposes a theoretical framework for the study of the relationships between culture, cognition and discourse, illustrated on the examples of conventionally assumed sociocultural knowledge that is encoded by language, on the one hand, and individually constructed sociocultural knowledge in discourse, on the other. It is argued that discourse construction is dependent on the context of sociocultural knowledge that participants obtain as members of various sociocultures. We claim that the context of sociocultural knowledge is a two-dimensional unity. Statically, it represents conceptual-and-thematic domains as cognitive models encoded by language. Dynamically, it profiles meanings participants make as the result of the interpretive process of selection, classification and evaluation that constitute the cognitive-discursive interpretant (CDI), a construct worked out in the article. Apart from constituting interpretation in discourse construction, the CDI is a technique for analyzing sociocultural discourse specificity. We present an account of what language users do when they activate sociocultural knowledge in the process of discourse construction and how they do it.

Keywords: context of sociocultural knowledge, static and dynamic aspects of context, cognitive models, cognitive-and-thematic domains, cognitive-discursive interpretant (CDI), selection, classification, evaluation.

\section{Introduction}

The idea of sociocultural discourse specificity is certainly not novel with the field of linguistics. While research on language use, discourse, culture and human mind has its origins in various disciplines, the work which was among the most influential came from psychology (originating most notably with L. Vygotsky) (2012), anthropology (Malinowski, 1989), social sciences (Fairclough, 2006), and linguistics, cognitive linguistics in particular (Lakoff, 1987, 2007; Langacker, 2000, 2007; Talmy, 2000).

L. Vygotsky's Social Development Theory has become the foundation of much scientific research on cognitive development over the past decades. In L. Vygotsky's view, meaning-making as well as individual development cannot be understood without reference to the sociocultural context within which they are embedded (Vygotsky, 2012). From an anthropological perspective, it is argued that what participants mean by what they say ultimately depends upon what their culture is (Malinowski, 1989). Within social sciences, the assumption has been that there is a constituting relationship between discourses and social systems in which they function; discourses are viewed as ideological systems of meaning (Fairclough, 2006).

In more recent research T. van Dijk argues that there has been "a theoretical shortcut ignoring the mental interface of participants' semantic and pragmatic mental models' (Dijk, 2009) and introduces "context" as a tool for analyzing the relation between discourse and society (Dijk, 2010). He claims that "a context is what is defined to be relevant in the social situation by the participants themselves" (Dijk, 2009), "a subjective mental model of such a situation" (Dijk, 2009). The model controls language production and understanding and explains how discourse is made appropriate in each situation, the finding that seems to date back to the works of cognitive linguistics (Boldyrev, 2012; 2013a; 2013b; 2014; Demyankov, 1994; Kubryakova, 2012; Lakoff, 1987; 2007; Langacker, 2000; 2007; Talmy, 2000).

Research over the past two decades has established that cross-cultural specificity of discourse 'mirrors' non-verbal cultural patterns of behavior (Larina, 2009; Kulikova, 2009; Scollon, 2001; Ting-Toomey, 1999). They are known as 
'contexts of culture' and 'cultural dimensions' and were elaborated in 1950th $-1970^{\text {th }}$ by E. Hall (Hall, 1976; 1990) and G. Hofstede (Hofstede, 2010). These findings, based initially on sociological data, have been supported by linguists as well. The differences of verbal interactions between representatives of different cultures have been and are still explained in terms of cultural and ethnic backgrounds of communicants rather than their individual sociocultural knowledge they acquire throughout life: "<...> our cultural and ethnic identities influence our verbal communication styles" (Ting-Toomey, 1998). On the other hand, cross-cultural discourse specificity is discussed within the framework of pragmatics that deals with the question of how to use language appropriately in social situations for different purposes (e.g., informing, demanding, promising, requesting), leaving the sociocultural knowledge of participants behind.

Validating the importance of cultural impact on discourse construction as well as that of intentionality, the argument we present in the paper is that individual knowledge which is obtained as a result of personal cognitive development and experience within particular sociocultures (family, school and other social structures) is of equal importance. That said, the study of sociocultural discourse specificity should take into account sociocultural context of discourse as a twodimensional unity reflecting ontogenetic and phylogenetic development of human cognition, i.e. systemic and dynamic dimensions of context of sociocultural knowledge.

The aim of the present paper is to elaborate the notion of 'context of sociocultural knowledge' by illustrating what language users do when they activate sociocultural knowledge in the process of discourse construction and how they do it. We argue that construing discourse involves referring to conceptual-and-thematic domains, drawing on vast cultural knowledge, on the one hand. Importantly, on the other hand, it activates profiling as a construal operation that emphasizes culture-bound conceptual characteristics, acquired by a participant in the process of socialization and associated as relevant in the ongoing process of interpretation.

The assumption is that discourse has a rich and complex structure that is the emergent consequence of the interplay of static and dynamic dimensions of context of sociocultural knowledge. Its first, static dimension reflects the diversity of conceptualizations, conventional knowledge of its participants included. The systemic dimension of sociocultural context maintains conventional knowledge of a particular society and culture as acquired in the processes of socialization and language learning. The second, dynamic dimension of sociocultural context refers to the conceptualand-thematic domain that exemplifies a particular society and culture and structures discourse content in terms of linguistic choices that represent it. Characterized by figure / ground organization, the context of sociocultural knowledge in discourse construction is seen as manifesting a general feature of cognition: a focus on an individual conceptual system that presupposes sociocultural knowledge which is activated in the process of discourse construction. This theoretical approach foregrounds a plausible tool for analyzing sociocultural specificity of discourse, the interrelation between individual and conventionally assumed knowledge, discourse construction and interpretation in the context of a language user's sociocultural experience, thus shaping a sociocultural approach to language performance as a subfield of cognitive semantics. In the present paper, the tool is referred to as 'cognitive-discursive interpretant' (CDI).

The argument presented in the paper is that while construing discourse we always make references to concepts and other conceptual structures within cognitive models, a major part of them being "conceptual-and-thematic domains" (Boldyrev, 2012) as mental structures that reflect the sociocultural experience humans obtain in their everyday lives (that of learning, working, living with particular members of the society and culture, encoded by language). The sociocultural knowledge is stored in such conceptual-and-thematic domains, as HUMAN BEINGS, ARTEFACTS, NATURE, WILDLIFE, SPACE, TIME (Boldyrev, 2012; 2013a; 2013b; 2014). These domains are specified into smaller subcategories (conceptual-and-thematic domain HUMAN BEINGS, for instance, specifies into PROFESSIONS, MALES, FEMALES).

That all said, the study of context of sociocultural knowledge in the process of interpreting and discourse construction constitutes relevant scientific knowledge about language use.

The paper is structured as follows. In the next section (2) we provide the methodological perspective by introducing the CDI for analyzing sociocultural discourse specificity. In section (3) we present the results of the sociocultural discourse specificity analysis. The last section (4) discusses the advantages of the advocated approach.

\section{Method}

In the past three decades, the study of discourse has become an important perspective for those concerned with the study of language use in a variety of social settings. A wide range of methods for analyzing discourse are available now. Among them are conversation analysis, critical discourse analysis, discursive psychology, Foucauldian discourse analysis, to mention only a few. All of them, being specific, are, ultimately, focused on the use of language in different contexts and study the ways participants make sense of the world within a given context. The analytical techniques, 
though, appear insufficient for analyzing how sociocultural knowledge is structured in discourse.

We argue that word choices and other language units alongside meaning-making process are constituent parts of cognitive-discursive interpretant, a term coined to describe the theoretical perspective on sociocultural knowledge of discourse underlying the framework within which sociocultural discourse specificity is assumed to be a participant's individual interpretative procedure.

Cognitive-discursive interpretant as a process of interpreting and discourse construction involves selection, classification, and evaluation that refer to particular concepts within particular contexts of sociocultural knowledge (Boldyrev 2012). Selection provides profiling, classification triggers the assignment of the profiled meaning to groups within a system of categorization, evaluation implies assessment within a set of norms, values, and other standards that a participant acquired as a member of a particular socioculture. As a cognitive structure, cognitive-discursive interpretant narrows interpretation in terms of a particular choice (selection), classification, and evaluation within a particular framework of sociocultural experience and knowledge.

As a research tool, cognitive-discursive interpretant is a technique that is served as the basis for interpreting the world and construing it in discourse. It has the critical task of exposing the mechanisms that underlie interpretation in discourse. It provides insights into the complex relationship among static and dynamic dimensions of context of sociocultural knowledge as it is constructed in discourse.

The approach advocated in the article has been influenced by the works of cognitive linguists (Demyankov, 1994; Evans, 2009; Fauconnier, 2007; Hart, 2010; Kubryakova, 2012). Indeed, resent research on discourse shows that discourse analyses draw on theories and methods developed in other disciplines, cognitive linguistics constituting a major part (e.g. Hart, 2010). Cognitive linguistics highlights an awareness of the necessity for interdisciplinary approach to language, cognition, and culture (e.g. Barsalou, 1992; Bergen, 2012).

The method for investigating sociocultural discourse specificity underpins the analysis of the corresponding sociocultural knowledge of a language user that constitutes the cognitive-discursive interpretant. Issues of validity of this argument are detailed in the next section.

\section{Results}

\subsection{Starting points}

The starting point of our approach is the assumption that cognition is structured not only by neurological capacity but is influenced by sociocultural parameters that shape knowledge of particular individuals, no matter what cultural or personal identity they demonstrate. Intellectual, linguistic and other types of activity as well as socialization and information storing are deeply rooted in the cognitive process of generating information which is culture-bound; the latter occurs within a particular socioculture. Participants compare, analyze, and organize information into discourse according to the sociocultural knowledge they obtain as active members of a particular socioculture. Social roles, values, norms, and other social modes result in the national, professional, religious, gender, age and other identities, the knowledge of which is culture-specific and affects discourse construction.

We argue that sociocultural parameters structure sociocultual knowledge that a language user possesses and mould its specificity. Mental, linguistic, social and other activities of language users as representatives of a particular social class, role, and cultural background contribute to different types of sociocultural contexts - contexts of sociocultural knowledge as mental constructions of the world. They are based on different types of identity levels to characterize a language user in terms of national, professional, religious, gender, age, etc. parameters. Sociocultual contexts shape cognition by structuring corresponding conceptual-and-thematic domains within which language users interpret the world and represent it in discourse.

Essentially, language use as discourse construction involves interpretation, i.e. activation of part of the cognitive model profile accessed via lexical concepts.

\subsection{Cognitive-discursive interpretant in the process of contextual discourse construction}

Cognitive-discursive interpretant is an interplay of static and dynamic dimensions of context of sociocultural knowledge.

Statically, sociocultural knowledge is revealed in language as a system of signs and via it. Selection, classification, and evaluation as cognitive operations occur within a context of sociocultural knowledge that prompts for the conventional construction of meaning.

Consider, for example, the following dictionary definitions that represent differences in the semantic values, in 
Evans's terms (Evans 2009), of the lexical concepts (FRUIT), (VEGETABLE), (TOMATO), (FRUKT), (OVOSCH), (POMIDOR) in the English and Russian languages: 1998);

Fruit - the parts of a tree or bush that contain seeds and are often eaten for their usually sweet flesh (Longman,

Vegetable - a part of a plant that is grown for food to be eaten in the main part of a meal, rather than with sweet things; vegetables are often eaten together with a piece of meat or fish (Longman, 1998);

Tomato - a soft fleshy juicy red fruit eaten raw or cooked as a vegetable (Longman, 1998);

Фрукт - сочный съедобный плод дерева (Frukt - sochnyiy s'edobnyiy plod dereva (Ozhegov, 1978); Fruit - is a juicy eatable part of a tree);

Овощи (овощ) - огородные плоды и зелень, употребляемые в пищу (например, огурцы, морковь, свекла, помидоры, брюква) (Ovoschi - ogorodnyie plodyi i zelen, upotreblyaemyie v pischu (naprimer, ogurtsyi, morkov, svekla, pomidory, bryukva) (Ozhegov, 1978); Vegetables (vegetable) are eatable kitchen garden plants, parsley and dill included);

Помидор - огородное растение семейства пасленовых, а также его округлый плод, обычно красного uвеma (Pomidor - ogorodnoe rastenie semeystva paslenovyih, a takzhe ego okruglyiy plod, obyichno krasnogo tsveta (Ozhegov, 1978); Tomato - is a kitchen garden plant of Solanaceae family, as well as its round-shaped eatable part usually of a red colour).

In the linguistic example fruit the selected semantic values are: 'parts of a tree', 'eaten', 'contain seeds', 'sweet'; in vegetable they are: 'eatable part of a plant', 'main part of a meal'. These semantic values are associated with scientific knowledge about (TOMATOES) that is represented by the encoded form tomatoes. However, everyday experience allows speakers of English adjust (classify) (TOMATOES) to the category of (VEGETABLES). Put another way, scientifically, (TOMATOES) are fruits; but they can be (VEGETABLES) on the menu. Scientific knowledge of (TOMATOES) as (FRUITS) underlies the decision made by JUSTIA US Supreme Court in 1893:

"Tomatoes are "vegetables," and not "fruit," within the meaning of the Tariff Act of March 3, 1883, c. $121<\ldots>$ Botanically speaking, tomatoes are the fruit of a vine, just as are cucumbers, squashes, beans, and peas. But in the common language of the people, whether sellers or consumers of provisions, all these are vegetables which are grown in kitchen gardens, and which, whether eaten cooked or raw, are, like potatoes, carrots, parsnips, turnips, beets, cauliflower, cabbage, celery, and lettuce, usually served at dinner in, with, or after the soup, fish, or meats which constitute the principal part of the repast, and not, like fruits generally, as dessert" (http://supreme.justia.com/cases/ federal/us/149/304/case.html).

In Russian, (POMIDOR) are vegetables (classification); the lexical concept is associated with everyday experience of speakers of the Russian language rather than scientific knowledge about (POMIDOR). The semantic values of the lexical concept are conventionally associated with the scientific knowledge, such as: eatable items growing on small bushes. Interestingly, (TOMAT) is associated with sauce that is served with other foods, as in the following dictionary definition:

Томат - пюре из помидоров (Tomat - pyure iz pomidorov (Ozhegov, 1978).

The words vegetable and frukt have at least two more conventional senses. Each conventional sense has associated with it the semantic values of evaluation. These include references to human beings who are ill (in case of vegetable) or mean (in case of frukt):

Vegetable: a human being who has little or no power of thought, or sometimes also movement, as in: Since she suffered brain damage in the accident she's just been a vegetable (Longman, 1998);

Фрукт - человек, от которого можно ожидать всяческих неприятностей, подозрительный и ненадежны (Ozhegov, 1978); Fruit - is a man you can't rely on, mean and suspicious).

Context of sociocultural knowledge serves as a scope of predication, in Langacker's terms (Langacker 2007), that provides a profile and a base, where the profile designates a conceptual structure within a larger unit, the base. Dynamic dimension of context holds a variety of meanings participants make in the process of discourse construction that reflect their sociocultural knowledge. In discourse, lexical concepts provide access to sociocultural knowledge relating to particular (not potential) activities and spheres of life. Overall, the CDI involves the activation of selection, classification, and evaluation within the context of sociocultural knowledge. Consider the examples:

(1) Cтоит на базаре, как на витрине, и любая баба, а их там тьсячи, может подойти и пощупать её мужа, как овощ (NKRYa) - Stoit na bazare, kak na vitrine, i lyubaya baba, a ih tam tyisyachi, mozhet podoyti i poschupat eYo muzha, kak ovosch ("When her (wife's) husband goes to the market, any woman can touch him as if he were a vegetable in a shop window"); 
(2) Как вы mерпите этот ужасный климат, вы ведь не питерский овощ, нет? (NKRYa) - Kak vyi terpite etot uzhasnyiy klimat, vyi ved ne piterskiy ovosch, net? ("How can you endure this unbearable climate, you are not a Saint Petersburg's vegetable?");

(3) Я уже засыпаю. Нужно спать, боюсь завтра просплю. Засыпай ))) В любом случае, это не самый худший способ времяпровождения ()) Ты тоже иди спать : -) а то завтра будешь как овощ : -) Да ладно, я утром высплюсь )) Впрочем, если ты настаиваешь...(NKRYa) - Ya uzhe zasyipayu. Nuzhno spat, boyus zavtra prosplyu. Zasyipay ))) $\mathrm{V}$ lyubom sluchae, eto ne samyiy hudshiy sposob vremyaprovozhdeniya ))) Tyi tozhe idi spat : -) a to zavtra budesh kak ovosch : -) Da ladno, ya utrom vyisplyus )) Vprochem, esli tyi nastaivaesh... ("I am falling asleep. It is time to go to bed. I am afraid I will be late tomorrow. Do that))) In any case, falling asleep is not such a bad activity ))) You'd better go as well :) otherwise you will be like a vegetable tomorrow. Never mind, I will sleep in the morning. But if you insist....");

(4) Молодые торопят время, желая казаться старше, а пожилые тормозят время, чтобы казаться моложе, однако, правда в том, что каждый из нас - овощ своего времени (NKRYa) - Molodyie toropyat vremya, zhelaya kazatsya starshe, a pozhilyie tormozyat vremya, chtobyi kazatsya molozhe, odnako, pravda v tom, chto kazhdyiy iz nas ovosch svoego vremeni ("Young people always make haste of time trying to be older. Old people try to stop the time in order to look younger. The truth, however, is that each of us is a vegetable of their proper time").

Sociocultural knowledge accessed by (OVOSCH) in (1) includes, at the very least, the knowledge about whether it is allowed or not to touch vegetables before buying them (it is, in Russia) and is represented by the concepts MARKET, SHOP WINDOW of the conceptual-and-thematic domain BUYING FOOD. The process of interpretation by virtue of CDI involves: i) selection of the conceptual structures of FAMILY RELATIONS that (HUSBAND), (WOMAN), (WIFE) provide access to; ii) categorizing the event (buying food) in terms of an intimate affair; iii) disapproval of the indifferent style of the man's behavior on the grounds that any woman can touch him (evaluation).

In (2) the participant activates the sociocultural knowledge about weather conditions in Saint Petersburg, Russia, by virtue of the lexical concepts (UNBEARABLE CLIMATE), (ENDURE), (VEGETABLE), (PETERSBURG) that provide access to it. It is represented by the concepts CLIMATE, WEATHER CONDITIONS, CITY ON THE NEVA RIVER of the conceptual-and-thematic domain LIVING IN A CITY. The CDI includes: i) selection of the conceptual structure of PLACE OF BIRTH that the lexical concepts (PETERSBURG), (WEATHER) provide access to; ii) categorizing the event (living in a city) in terms of the unsuitable territory for growing fruits; iii) referring to a feeling of distaste (evaluation).

In (3) the sociocultural knowledge relates to the farmers' experience they obtain while storing vegetables. The CDI is activated by: i) the selection of the lexical concepts (FALLING ASLEEP), (SLEEPLES NIGHT) providing access to cognitive models IMPORTANCE OF GOOD STORING CONDITIONS, IMPORTANCE OF A NIGHT'S REST; ii) categorizing the event (falling asleep at an inappropriate time) in terms of looking and feeling bad in the morning; iii) giving advice to the friend (evaluation).

In (4) the sociocultural knowledge relates to the farmers' experience they obtain while growing vegetables. The $\mathrm{CDI}$ is activated by: i) the selection of the lexical concepts (YOUNG), (OLD), (PROPER TIME) providing access to cognitive models YOUN PEOPLE WANT TO BECOME GROWNUPS, OLD PEOPLE WANT TO BE YOUNG AGAIN; ii) categorizing the event (everything is in its own place and at the right time) in terms of ripening of vegetables; iii) asserting the truth (evaluation).

The point of this section has been to show that context of sociocultural knowledge in discourse has two statuses: i) static, relating to conventionally assumed knowledge encoded by language and ii) dynamic that foregrounds individually construed meanings of participants as members of particular sociocultures (e.g., performing particular activities, living on particular territories). Lexical concepts give access to cognitive models that profile the sociocultural knowledge by virtue of the CDI. On the one hand, the CDI activates selection, classification, and evaluation. On the other hand, it is a tool that exemplifies the context of sociocultural knowledge of a participant. The CDI is a consequence of interpretation in discourse construction.

\section{Discussion}

In the present paper we offer a perspective on particular issues that have been addressed by scholars of various subfields of linguistics. It is named 'sociocultural discourse specificity' and is seen as interfacing with a number of specific theories in Cognitive linguistics.

We have provided an overall framework to conduct sociocultural discourse analysis in Cognitive linguistics by introducing the $\mathrm{CDI}$ as a technique revealing cognitive operations of selection, classification, and evaluation that 
characterize interpretation in discourse.

The CDI has its own special characteristics. It clearly demonstrates that sociocultural discourse specificity is dependent on sociocultural knowledge of its participants that they obtain as members of particular sociocultural backgrounds rather than cultural dimensions or personal intentions, the approaches still relevant in cross-cultural discourse studies. The sociocultural knowledge is stored in conceptual-and-thematic domains that consist of a large body of knowledge, represented in the context of sociocultural knowledge in discourse, i.e. cognitive models that are profiled by virtue of $\mathrm{CDI}$.

Specifically, we have claimed that in the process of discourse construction by virtue of lexical concepts language users profile conceptual structures that represent them as members of particular sociocultures. They do this by cognitive operations of selection, classification, and evaluation.

Finally, the CDI may be applied to various discourse data to enhance deeper understanding of cultural differences in speech by representatives of different social and cultural backgrounds.

\section{References}

Barsalou, L. W. (1992). Cognitive Psychology: an Overview for Cognitive Scientists University of Chicago. Chicago: Psychology Press. Bergen, B. K. (2012). Louder than words. Basic Books.

Boldyrev, N.N. (2013a). Interpretatsionnyiy potentsial kontseptualnoy metafory. Kognitivnyie issledovaniya yazyika. Moscow: In-t yazyikoznaniya RAN, $12-22$.

Boldyrev, N.N. (2014). Kontseptualno-tematicheskie oblasti yazyikovoy kartinyi mira i ih interpretiruyuschaya funktsiya. Kognitivnyie issledovaniya yazyika. Moscow: In-t yazyikoznaniya RAN, 33-39.

Boldyrev, N.N. (2013b). Strukturirovanie opyita i integrirovanie smyisla v vyiskazyivanii. Kognitivnyie issledovaniya yazyika. Moscow: In-t yazyikoznaniya RAN, 18-29.

Boldyrev, N. N. (2012). K voprosu ob integrativnoy teorii reprezentatsii znaniy v yazyike. Kognitivnyie issledovaniya yazyika, 33-43.

Demyankov, V.Z. (1994). Kognitivnaya lingvistika kak raznovidnost interpretiruyuschego podhoda. Voprosyi yazyikoznaniya, 4, 17-33.

Dijk, T. A van. (2010) Discourse and Context: a Sociocognitive Approach. Cambridge: Cambridge University Press.

Dijk, T. A van. (2009) Society and Discourse: how Social Contexts influence Text and Talk. Cambridge: Cambridge University Press.

Evans, V. (2009). How words mean: lexical concepts, cognitive models, and meaning construction. Oxford University Press.

Fairclough, N. (2006) Analysing Discourse: textual analysis for social research. New York: Routledge.

Fauconnier, G. (2007) Conceptual Integration Networks. In V. Evans, B. Bergen, J. Zinken (eds) The Cognitive Linguistics Reader. London: Equinox, 360-419.

Hall, E. T. (1976) Beyond Culture. Canada: Random House.

Hall, E. T. (1990) The Silent Language. New York: Anchor Books; Random House.

Hart, Ch. (2010) Critical discourse analysis and cognitive science: new perspectives on immigration discourse. Palgrave MacMillan.

Hofstede, G. (2010) Cultures and Organizations: Software of the Mind. Intercultural Cooperation and Its Importance for Survival. USA.

Kubryakova, E. S. (2012) V poiskah suschnosti yazyika. Kognitivnyie issledovaniya. Moscow: Znak.

Kulikova, L. V. (2009) Kommunikativnyiy stil v mezhkulturnom obschenii. Moscow: Flinta, Nauka.

Lakoff, G. (2007) The Contemporary Theory of Metaphor. In V. Evans, B. Bergen, J. Zinken (eds) The Cognitive Linguistics Reader. London: Equinox, 267-315.

Lakoff, G. (1987) Women, Fire, and Dangerous Things. What Categories Reveal about the Mind. Chicago: The University of Chicago Press.

Langacker, R. (2007) An Introduction to Cognitive Grammar. In V. Evans, B. Bergen, J. Zinken (eds) The Cognitive Linguistics Reader. London: Equinox, 444-480.

Langacker, R. W. (2000) Grammar and Conceptualization. Berlin: Mouton de Gruyter.

Larina, T. V. (2009) Kategoriya vezhlivosti i stil kommunikatsii: sopostavlenie angliyskih i russkih lingvokulturnyih traditsiy. Moscow: Rukopisnyie pamyatniki Drevney Rusi.

Longman Dictionary of English Language and Culture (1998). Edinburgh Gate: Longman.

Malinowski, B. A. (1989) Diary in the Strict Sense of the Term. Stanford: Stanford University Press.

NKRYa (National Corpus of the Russian language). Retrieved from: http://www.ruscorpora.ru

Ozhegov, S. I. (1978). Russian Language Dictionary. Moscow: Russian Language.

Scollon, R. (2001) Intercultural Communication: Discourse Approach. Blackwell: Blackwell Publishing.

Talmy, L. (2000) Toward a Cognitive Semantics. Cambridge; London: MIT Press: A Bradford Book, Vol. 1.

Talmy, L. (2000) Towards a Cognitive Semantics. Cambridge; London: MIT Press: A Bradford Book, Vol. 2.

Ting-Toomey, S. (1999) Communicating Across Cultures. New York; London: The Guilford Press.

Vygotsky, L. S. (2012) Thought and Language: revised and expanded edition. Cambridge, Massachusetts: The MIT Press. 